\title{
Nurses in strengthening management and action on tuberculosis control
}

The TB control is considered in the Millennium Development Goal number six, whose goal is to reduce the incidence of the disease until 2015. Despite progress in terms of reducing the number of cases of the disease, although it is estimated that million people are suffering from tuberculosis every year and a large proportion of these are lost by national programs tuberculosis. ${ }^{1}$

It is widely recognized that without significant increase in funding and political commitment, there are no prospects for disease control. Consequently, 50 million people will continue to develop active TB, more than 10 million people will die and more than 2 million cases of multidrug arise requiring specialized assistance. $^{2}$

Political commitment, and ensure availability of money, should also include heavy investments in qualifying policies, strategies action (approach centered on the patient and the community) and human resources (awareness and encouragement of health professionals). No policy will succeed or achieve the proposed goals if you do not have technically trained human resources and committed to the health of the population.

Act in the field of health, especially in the field of primary care and morbidities strong social determination as tuberculosis, requires in the first instance of a social commitment, interest in contributing to improving living conditions and health of people. That commitment is inherent in the condition of healthcare. However, in practice, the performance often does not correspond to a promoter and advocate of physical and mental health of people in the different fields of action of the health system nurse.

Collectively analyze and discuss this issue is urgent, especially because it is tuberculosis, a disease so known scientifically as old and very present, despite the great technological advances and medicines available in several countries. We cannot remain idle or indolent before the effects that cause disease in people's lives. Tuberculosis subject the patient to a position of social isolation and physical impairment physically disabled and generates a highly negative economic and emotional impact. This situation is even more serious when the disease occurs in the most virulent form (or multidrug resistant bacillus). Multiresistant tuberculosis and is a current and growing reality in several countries. This situation places once more the need for more and better fight to disease.

Certainly a strategic vision to expand and qualify the actions of disease control requires special attention of human potential that each health system has, specifically nursing professionals.

The important labor of nurses is recognized, despite the multifactorial explaining the permanence of tuberculosis. It is undeniable the role of this professional and potential in management, attention, care and surveillance of tuberculosis.

Nurses are on the front line of action in providing services and play an important role in patientcentered care. In many countries are leaders or key players in the multidisciplinary and interdisciplinary teams of health.

Studies show recognition of the active participation of nurses in care coordination, ${ }^{3}$ preferential searches among members of the health team, by the degree of freedom, ease of communication and trust of users, legitimizing their practices and placing them as facilitators of attention. ${ }^{4}$ 
In the context of primary care, nurses are considered accessible and concerned with human and willing to contribute in solving problems professional life. ${ }^{4}$ This aspect is key in the primary health care and more attention even in people with tuberculosis.

Investing in professional nurse for the implementation and maintenance of the actions of detection and treatment of tuberculosis, at different levels of performance in the health system, it can be an important solution, or a human resource with high potential for contribution, compared many other technological solutions adopted in which high financial resources consumed.

Nurses can be great allies to think about how to maintain, strengthen and implement new approaches to detect and treat tuberculosis. They can still significantly help adapt the strategies of action to the current reality, and even how to reach people who do not they access to health services when they have symptoms of tuberculosis, how to integrate effectively and safely participation family, university and the general population to face the disease. It is worthwhile experiences and promotes greater management opportunities, attention, care and surveillance of tuberculosis. Probably best results would be identified in the control of tuberculosis.

\section{BIBLIOGRAPHIC REFERENCES}

1. Stop TB Parthership. Improving Tuberculosis Case Detection [internet]. Geneva-Switzerland: Stop TB Parthership; 2013 [citado: 10 dic 2014]. Disponible en: ]http://www.stoptb.org/assets/documents/resources/publications/technical/TB_Case_Studies.pdf

2. Stop TB Partnership. La tuberculosis y los objetivos de desarrollo del milenio [internet]. GenevaSwitzerland: Stop TB; s.f. [citado: 10 de dic 2014]. Disponible en: http://www.stoptb.org/assets/documents/resources/factsheets/stopTB-factsheet_Spanish.pdf

3. Giovanella L, Escorel S, Mendonça MHM. Estudio de caso sobre implementación de la estrategia salud de la familia en cuatro grandes centros urbanos: informe de la investigación. Rio de Janeiro: ENSP/DAPS/NUPES, 2009.

4. Pereira CMO, Alves M. A participação do enfermeiro na implantação do programa de saúde da la família em Belo Horizonte. Rev Bras Enferm, Brasilia [serie de internet]. Mai-jun 2004 [citado: 26 de ago 2012]; 57(3): 311-5. Disponible en: http://www.scielo.br/pdf/reben/v57n3/a11v57n3.pdf

5. Santos RM, Ribeiro LCC. Percepção do usuário da estratégia saúde da família sobre a função do enfermeiro. Cogitare Enferm [serie de internet]. Out-dez 2010 [citado: 12 de ago 2013]; 15(4): 709-15. Disponible en: http://ojs.c3sl.ufpr.br/ojs2/index.php/cogitare/article/viewArticle/20373.

Ph. Roxana Isabel Cardozo Gonzáles Investigadora, Miembro de la Red Nacional de Tuberculosis/ Brasil Docente en la Universidad Federal de Pelotas/RS/Brasil

E-mail: roxana_cardozo@hotmail.com 